Aims. To promote co-operation in the Baltic Sea region in the field of trade, investment and economic exchanges, combating organized crime, civil security, culture and education, transport and communication, energy and environment, human rights and assistance to democratic institutions.

The Council meets at ministerial level once a year, chaired by rotating foreign ministers; it is the supreme decision-making body. Between annual sessions the Committee of Senior Officials and three working groups meet at regular intervals. In Oct. 1999 ministers of energy of the CBSS member states agreed to achieve the goal of creating effective, economically and environmentally sound and more integrated energy systems in the Baltic Sea region. Seven summits at the level of heads of government of CBSS member states and the President of the European Commission have taken place; in 1996, 1998, 2000, 2002, 2004, 2006 and 2008. The Baltic Sea Region Energy Cooperation (BASREC) is made up of energy ministers from the region and is chaired by the energy minister from the chair country of the CBSS.

Official language: English.

CBSS Secretariat: Strömsborg, PO Box 2010, S-103 11

Stockholm, Sweden.

Website: http://www.cbss.st

Director of the Secretariat: Dr Gabriele Kötschau (Germany).

\section{European Broadcasting Union (EBU)}

Founded in 1950 by western European radio and television broadcasters the EBU is the world's largest professional association of national broadcasters, with 75 active members in 56 countries of Europe, North Africa and the Middle East, and 45 associate members worldwide.

The EBU merged with the OIRT, its counterpart in eastern Europe, in 1993. The EBU's Eurovision Operations Department has a permanent network offering 50 digital channels on five satellites. Two satellite channels also relay radio concerts, operas, sports fixtures and major news events for Euroradio.

Headquarters: Ancienne Route 17, CH-1218 Grand-Saconnex, Geneva, Switzerland.

Website: http://www.ebu.ch

Email: ebu@ebu.ch

\section{Black Sea Economic Cooperation (BSEC)}

Founded in 1992 to promote economic co-operation in the Black Sea region. Priority areas of interest include: trade and economic development; banking and finance; communications; energy; transport; agriculture and agro-industry; healthcare and pharmaceutics; environmental protection; tourism; science and technology; exchange of statistical data and economic information; combating organized crime, illicit trafficking of drugs, weapons and radioactive materials, all acts of terrorism and illegal immigration.

Members. Albania, Armenia, Azerbaijan, Bulgaria, Georgia, Greece, Moldova, Romania, Russia, Serbia, Turkey, Ukraine.

Observers. Austria, Belarus, Black Sea Commission, Commission of the European Communities, Croatia, Czech Republic, Egypt,
Energy Charter Secretariat, France, Germany, International Black Sea Club, Israel, Italy, Poland, Slovakia, Tunisia, USA.

The Parliamentary Assembly of the Black Sea Economic Cooperation is the BSEC parliamentary dimension. The BSEC Business Council is composed of representatives from the business circles of the member states. The Black Sea Trade and Development Bank is considered as the financial pillar of the BSEC. There is also an International Center for Black Sea Studies and a Coordination Center for the Exchange of Statistical Data and Economic Information.

Headquarters: Sakıp Sabancı Caddesi, Müşir Fuad Paşa Yalısı, Eski Tersane 34460, İstanbul, Turkey.

Website: http://www.bsec-organization.org

Secretary-General: Leonidas Chrysanthopolous (Greece).

\section{Danube Commission}

History and Membership. The Danube Commission was constituted in 1949 according to the Convention regarding the regime of navigation on the Danube signed in Belgrade on 18 Aug. 1948. The Belgrade Convention, amended by the Additional Protocol of 26 March 1998, declares that navigation on the Danube from Kelheim to the Black Sea (with access to the sea through the Sulina arm and the Sulina Canal) is equally free and open to the nationals, merchant shipping and merchandise of all states as to harbour and navigation fees as well as conditions of merchant navigation. The Commission holds annual sessions and is composed of one representative from each of its 11 member countries: Austria, Bulgaria, Croatia, Germany, Hungary, Moldova, Romania, Russia, Serbia, Slovakia and Ukraine.

Functions. To ensure that the provisions of the Belgrade Convention are carried out; to establish a uniform buoying system on all navigable waterways; to establish the basic regulations for navigation on the river and ensure facilities for shipping; to coordinate the regulations for river, customs and sanitation control as well as the hydrometeorological service; to collect relevant statistical data concerning navigation on the Danube; to propose measures for the prevention of pollution of the Danube caused by navigation; and to update its recommendations regularly with a view to bringing them in line with European Union regulations on inland waterway navigation.

Official languages: German, French, Russian.

Headquarters: Benczúr utca 25, H-1068 Budapest, Hungary.

Website: http://www.danubecom-intern.org

Email: secretariat@danubecom-intern.org

President: Igor Savolskiy (Russia).

Director-General: István Valkár (Hungary).

\section{European Trade Union Confederation (ETUC)}

Established in 1973, the ETUC is recognized by the EU, the Council of Europe and EFTA as the only representative crosssectoral trade union organization at a European level. It has grown steadily with a membership of 82 National Trade Union Confederations from 36 countries and 12 European Industry Federations with a total of $60 \mathrm{~m}$. members. The Congress meets 